\title{
Observations of production and emission of greenhouse gases and ammonia during storage of solids separated from pig slurry: Effects of covering
}

\author{
M.N. Hansen ${ }^{\mathrm{a}, *}$, K. Henriksen ${ }^{\mathrm{b}}$, S.G. Sommer ${ }^{\mathrm{a}}$ \\ ${ }^{a}$ Danish Institute of Agricultural Sciences, Department of Agricultural Engineering, Schüttesvej 17, DK-8700 Horsens, Denmark \\ ${ }^{\mathrm{b}}$ Aalborg University, Institute of Life Sciences, Environmental Engineering Section, Sohngaardsholmsvej 57, 9000, Aalborg
}

Received 6 September 2005; received in revised form 26 January 2006; accepted 2 February 2006

\begin{abstract}
Separation of slurry produces a solid fraction that is stored in manure heaps before being used as a fertiliser in crop production. Considerable amounts of ammonia $\left(\mathrm{NH}_{3}\right)$ and greenhouse gases may be emitted during storage, which has deleterious environmental effects. The emission levels can be expected to depend on oxygenation level inside the bulk of the stored manure and therefore on storage conditions. An experiment was thus set up to study gaseous emissions during storage of the solid fraction, and the effects of the oxygenation of manure heaps on emissions of $\mathrm{NH}_{3}$ and various greenhouse gases. Emissions of $\mathrm{NH}_{3}$ and the greenhouse gases methane $\left(\mathrm{CH}_{4}\right)$, nitrous oxide $\left(\mathrm{N}_{2} \mathrm{O}\right)$, and carbon dioxide $\left(\mathrm{CO}_{2}\right)$ from an uncovered and covered heap of solids separated from pig slurry were compared, and related to the oxygenation level inside the manure heap. Approximately $15 \%$ of the initial nitrogen content was lost when separated solids were stored uncovered. Of the initial nitrogen content, $4.8 \%$ was lost as $\mathrm{N}_{2} \mathrm{O}, 0.3 \%$ was lost as $\mathrm{NH}_{3}$, while the $9.6 \%$ unaccounted for was assumed lost as dinitrogen $\left(\mathrm{N}_{2}\right)$. Of the initial carbon content, $28 \%$ was lost during uncovered storage; the majority of this was emitted as $\mathrm{CO}_{2}(25 \%)$, while $1.3 \%$ was emitted as $\mathrm{CH}_{4}$. Oxygenation level inside the heap was found to influence the production and emission of greenhouse gases. Covering the heap with an airtight material delayed aeration of the bulk of the stored manure, which reduced the internal heat production, degradation of organic matter, and emission of $\mathrm{NH}_{3}$ and greenhouse gases. Emissions of $\mathrm{NH}_{3}, \mathrm{~N}_{2} \mathrm{O}$, and $\mathrm{CH}_{4}$ were reduced by $12 \%, 99 \%$, and $88 \%$, respectively, when the manure heap was covered with an airtight material.
\end{abstract}

(C) 2006 Elsevier Ltd. All rights reserved.

Keywords: Solid manure; Separation; Ammonia; Methane; Nitrous oxide

\section{Introduction}

Slurry separation is a technology that separates slurry into a minor solid fraction containing a

\footnotetext{
*Corresponding author. Tel.: + 4589993036 ; fax: +4589993100 .

E-mail address: martinn.hansen@agrsci.dk (M.N. Hansen).
}

majority of the dry matter and phosphorus content of slurry, and a larger liquid fraction containing most of the ammonium-nitrogen and potassium content (Møller et al., 2002). In Denmark, slurry separation is mainly performed to reduce the risk of phosphorus accumulation on agricultural land in areas of dense livestock production, as it allows the transport of slurry phosphorus at a lower cost due 
to the volume reduction (Møller et al., 2000a). The solid fraction produced by slurry separation has a high phosphorus content and is therefore used as a fertilizer in crop production. Before being used it is stored in heaps, in which aerobic conditions normally allow composting (Eghball et al., 1997; Hao and Chang, 2001). Composting is caused by high microbial activity, which increases the temperature, $\mathrm{pH}$, and decomposition of organic matter of the manure (Møller et al., 2000b; Amon et al., 2001; Beck-Friis, 2001; Sommer, 2001). As the potential for ammonia emission is increased by the elevation of temperature and $\mathrm{pH}$ taking place during the composting of solid manure (Dewes, 1996), a significant part the initial nitrogen (N) content of solid manure may be lost during storage (Eghball et al., 1997; Petersen et al., 1998; Sommer and Dahl, 1999; Møller et al., 2000b; Misselbrook et al., 2001; Webb et al., 2001). It has been shown that the emission of ammonia from solid manure heaps can be reduced by covering (Webb et al., 2001, Sommer, 2001; Chadwick, 2005; Sagoo et al., 2005), so solid manure heaps in Denmark have to be covered with either air-permeable or airtight covering material. However, a side-effect of such airtight covering is a reduction of the oxygen $\left(\mathrm{O}_{2}\right)$ concentration inside the heap, which may affect the production and emission of greenhouse gases.

Agriculture contributes significantly to greenhouse-gas emissions, primarily due to the emission of methane $\left(\mathrm{CH}_{4}\right)$ and nitrous oxide $\left(\mathrm{N}_{2} \mathrm{O}\right)$. Scandinavian inventories have estimated that greenhouse-gas emissions from agriculture account for between $7 \%$ and $16 \%$ of total national emissions, of which manure handling contributes 11\% (Rypdal, 2002). Development of effective manure-management technologies is thus crucial if countries are to meet their Kyoto Protocol commitments to reduce greenhouse-gas emissions (UNFCCC, 1999). Significant amounts of $\mathrm{CH}_{4}$ and $\mathrm{N}_{2} \mathrm{O}$ are emitted during the storage of solid manure (Hellebrand, 1998; Sommer and Møller, 2000; Hellebrand and Kalk, 2001a). Livestock manure may account for $6 \%$ to $10 \%$ of annual global emissions of $\mathrm{CH}_{4}$ (Safely et al., 1992), whose global-warming potential has been estimated to be 21 times higher than that of $\mathrm{CO}_{2}$ (Houghton et al., 1996). Production of $\mathrm{CH}_{4}$ only takes place in anaerobic environments, while the less active greenhouse gas $\mathrm{CO}_{2}$ is produced when carbon degradation takes place in aerobic environment (Brock and Madigan, 1988). Nitrous oxide is another important greenhouse gas which has a global-warming potential 310 times higher than that of $\mathrm{CO}_{2}$ (Houghton et al., 1996). Nitrous oxide is produced by nitrification processes taking place in aerobic environments (Bremner and Blackmer, 1989) and by denitrification of nitrate in anaerobic environments (Hüther et al., 1997). Emission of both $\mathrm{CH}_{4}$ and $\mathrm{N}_{2} \mathrm{O}$ will therefore be influenced by the oxygenation level of the stored solid manure, which again can be expected to be influenced by covering. The present study was carried out to investigate how covering of heaps of solids separated from pig slurry effects production and emission of greenhouse gases and ammonia.

\section{Materials and methods}

\subsection{Manure}

Anaerobically digested pig slurry was separated using a decanting centrifuge (model NX 309, Alfa Laval Corp., Glinde, Germany). Thirteen tonnes of the solid fraction thus produced was immediately transferred into two identical cone-shaped heaps (height $=1.5 \mathrm{~m}, \quad$ diameter $=4.8 \mathrm{~m}$ ), which were stored for 4 months. The bulk density of the heaps was calculated to be $0.7 \mathrm{t} \mathrm{m}^{-3}$. One heap was stored uncovered (uncover) while the other was covered with a plastic sheet $(0.15-\mathrm{mm}$ polyethylene) (cover). To reduce inflow of air to the covered heap, the edges of the plastic sheet were covered with a sand layer. The impact of rain was simulated by weekly irrigation of the uncovered heap. Water was added in quantities corresponding to the registered weekly rainfall; however, to avoid leaching, addition did not exceed the absorbent capacity of the heap. The composition of manure was determined both before and after the storage period by analysing 8 representative samples per treatment. Each sample consisted of 10 subsamples of ca. $100 \mathrm{~g}$ each representatively taken by hand from the different regions of the heap. Each sample was thoroughly mixed in plastic bags to avoid volatilisation of $\mathrm{NH}_{3}$ before ca. $100 \mathrm{~g}$ was analysed using standard techniques. Dry matter (DM) was determined after drying samples at $100^{\circ} \mathrm{C}$ for $24 \mathrm{~h}$, ash content by combustion analyses (Carbolite, EØF 71/250), total nitrogen $(\mathrm{N})$ and total carbon $(\mathrm{C})$ by the Dumas procedure (LECO, CN 2000, Michigan, USA), total ammoniacal N (TAN) with an Lachat Autoanalyser (DS/EN, ISO 11732), and $\mathrm{pH}$ of the samples, mixed with demineralised water $(1: 1 \mathrm{~V}: \mathrm{V})$, was measured with a standard electrode (Type 704, Metrohm, 
Herisau, Switzerland). Total loss, during storage, of wet weight (ww), DM, ash, N, and $\mathrm{C}$ were determined by the differences of mass determined before and after the storage period.

\subsection{Dynamic chambers}

The heaps were stored in identical dynamic chambers $(15.6 \mathrm{~m} \times 7.3 \mathrm{~m}$ and $4.5 \mathrm{~m}$ tall $)$. The concrete floor of each chamber sloped to a central drain to allow for collection of effluent. The emission chambers were equipped with internal ventilators to simulate wind and to ensure mixing of internal air. A ventilator situated in the ceiling of each chamber drew air through the chambers at a preset flow rate of $0.7 \mathrm{~m}^{3} \mathrm{~s}^{-1}$ allowing that chamber air was changed 4.9 times per hour; however, actual air flow was determined continuously throughout the measurement period by a pre-calibrated freerunning impeller mounted in each ventilating duct. Samples of inflowing and outflowing air were transported through heated and insulated Teflon tubes (id $=3.0 \mathrm{~mm}$ ) to a Photoacoustic Multi-gas Monitor (Model 1312, INNOVA, Copenhagen, Denmark), which measured concentrations of $\mathrm{CO}_{2}, \mathrm{CH}_{4}, \mathrm{~N}_{2} \mathrm{O}, \mathrm{NH}_{3}$, and air humidity every $10 \mathrm{~min}$ throughout the $120 \mathrm{~d}$ storage period. Emissions of the different gases were quantified using the following equation:

$E=\sum_{j=1}^{n}\left(C_{\text {out } j}-C_{\text {inj } j}\right) V_{j}$

where $E$ is the total emission in $\mathrm{mg}$ of a specified gas, $j$ is the number of observations, $n$ is the total number of observations, $V$ is volume of air flow in $\mathrm{m}^{3}$, and $C_{\text {out }}$ and $C_{\text {in }}$ are, respectively, the concentration of gas in outlet and inlet air in $\mathrm{mg} \mathrm{m}^{-3}$ air.

\subsection{Composition of gas phase inside the bulk of the heaps}

For determining $\mathrm{CO}_{2}, \mathrm{CH}_{4}, \mathrm{~N}_{2} \mathrm{O}$, and oxygen $\left(\mathrm{O}_{2}\right)$ concentration inside the heaps, gas samples were collected from different depths in the heaps using a modification of the technique described by Petersen et al. (1998). Two flexible, but rigid plastic tubes $(l=4.0 \mathrm{~m}$, id $=10 \mathrm{~mm})$ were placed inside each heap at establishment. Both tubes were positioned $0.2 \mathrm{~m}$ above the base of the heaps, one $0.1 \mathrm{~m}$ below the surface of the heaps (surface), and the other in the centre of the heaps (centre). Air could diffuse into the tubes through $3.0-\mathrm{mm}$ holes per $\mathrm{cm}$ length. Both ends of the tubes were connected with two 2-m lengths of gas-tight FEB tubes to gas-tight diaphragm pumps (Rietshle Thomas, type 5002, Maribo, Denmark), situated outside the heaps This allowed circulation of air inside the closed tube systems prior to air sampling. With syringes, two samples of $50 \mathrm{ml}$ were sucked from the tubes and transferred to 5-ml glass bottles fitted with butyl rubber septa. Sampling was performed on daily basis the first week after heap establishment, thereafter twice weekly throughout the storage period. When transferring a sample to a glass bottle, an extra needle was inserted through the rubber seal and the bottle was flushed with $35 \mathrm{ml}$ of the gas from the syringes; then the needle penetrating the septa was removed and the $15 \mathrm{ml}$ remaining in the syringes was injected into the glass bottle. Gas concentrations in the glass bottles were determined by means of gas chromatographic analyses (Hewlett-Packard 5890 Series II gas chromatograph, Minnesota, USA) equipped with an electron capture detector (ECD) detector for determination of $\mathrm{N}_{2} \mathrm{O}$ concentrations, and a flame ionization detector (FID) for determination of $\mathrm{CH}_{4}$ concentrations, and (Perkin Elmer, Clarus 500, Boston, USA) equipped with a thermal conductivity detector (TCD) for determination of $\mathrm{O}_{2}$ and $\mathrm{CO}_{2}$ concentrations. Temperature was automatically measured and recorded by Testostor data loggers (Model 175, Testo Inc., Wien, Austria) at 10-min intervals at the same depths as the sampling tubes, and in addition, $0.7 \mathrm{~m}$ below the heap surface (intermediate).

\subsection{Statistical analysis}

The influence of storage and storage treatment on manure composition was statistically analysed using the generalised linear model (GLM) procedure (SAS Institute, 1988). Assumption of equal variance of different groups was tested using Bartlett's test prior to analysis. Where significant treatment effects within groups were found by analysis, Duncan's multiple range test was used to test for significant differences of means. For all the statistics, a significance level of $\alpha=0.05$ was applied. As production of gases inside heaps and emission from the heaps were not replicated, no statistical analyses were applied to gas concentration inside the manure heaps and to emission of gases from the differently treated manure heaps. 


\section{Results}

\subsection{Temperature and concentrations of $\mathrm{O}_{2}, \mathrm{~N}_{2} \mathrm{O}$ and $\mathrm{CH}_{4}$ inside the heaps}

Immediately after establishment of the heaps the entire mass of stored manure was anaerobic (Fig. 1). In the uncovered heap, the $\mathrm{O}_{2}$ concentration near the surface increased rapidly within $1-2 \mathrm{~d}$, but did not reach ambient concentrations until $60 \mathrm{~d}$; whereas $\mathrm{O}_{2}$ concentrations remained low in the centre part throughout the measurement period, except for a periodic increase taking place after 90-120 d storage (Fig. 1a). In the covered heap, low concentrations of $\mathrm{O}_{2}$ were observed both in the centre and near the surface until 90 to $120 \mathrm{~d}$ of storage, when $\mathrm{O}_{2}$ concentrations temporarily increased (Fig. 1b).

Temperature inside the uncovered heap increased rapidly after establishment. Temperatures were observed to be highest near the surface of the heap; however, in this area temperature declined to near ambient temperature within $30 \mathrm{~d}$ of commencement of storage. In the intermediate and centre zones of
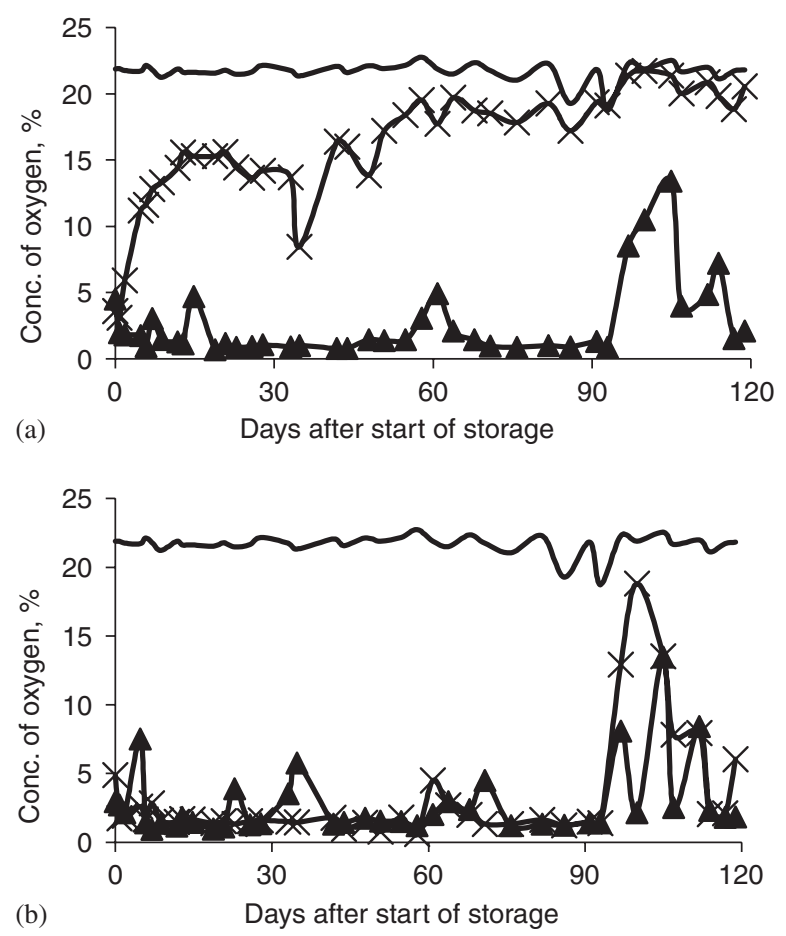

Fig. 1. Oxygen concentrations in solids separated from pig slurry when stored in an uncovered (a) and covered (b) heap. Concentrations were determined $0.1 \mathrm{~m}$ below heap surface $\times-$, in the centre of heaps $-\mathbf{\Delta}-$, and in ambient air - . the uncovered heap, temperatures increased to between 30 and $40^{\circ} \mathrm{C}$ during the first weeks of storage and remained high thereafter (Fig. 2a).

In the covered heap, temperatures increased initially to ca. $30^{\circ} \mathrm{C}$ in all zones, but after $7-30 \mathrm{~d}$ temperatures gradually declined to ambient levels (Fig. 2b).

The concentration of $\mathrm{N}_{2} \mathrm{O}$ in the uncovered heap increased in the outer layers after $14 \mathrm{~d}$ of storage to reach maximum concentration after $20-40 \mathrm{~d}$, where after $\mathrm{N}_{2} \mathrm{O}$ concentrations gradually declined to reach ambient levels after $40-120 \mathrm{~d}$ of storage (Fig. 3a). A minor increase in $\mathrm{N}_{2} \mathrm{O}$ concentrations in the centre of the uncovered heap took place after $60 \mathrm{~d}$ of storage. In contrast, no increase in $\mathrm{N}_{2} \mathrm{O}$ concentration was observed inside the covered manure heap (Fig. 3b).

Concentrations of $\mathrm{CH}_{4}$ in the centre of the uncovered manure heap increased during the first $30 \mathrm{~d}$ of storage, after which they gradually declined toward ambient levels. The highest concentrations were observed in the central part of the heap (Fig. 4a). Methane concentrations inside the manure were substantially decreased by covering;
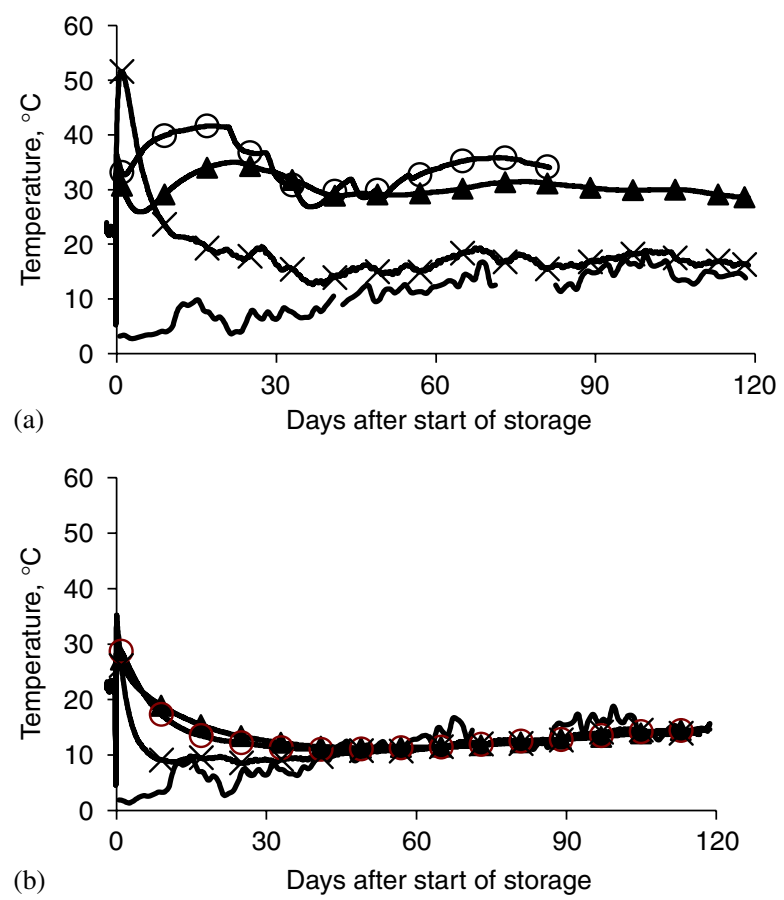

Fig. 2. Development of temperatures in different regions in solids separated from pig slurry when stored in an uncovered (a) and covered (b) heap. Temperatures were determined $0.1 \mathrm{~m}$ below heap surface $-\times-, 0.7 \mathrm{~m}$ below heap surface $-\mathrm{O}-$, in the centre of the heap $-\mathbf{\Delta}-$, and in ambient air - . 

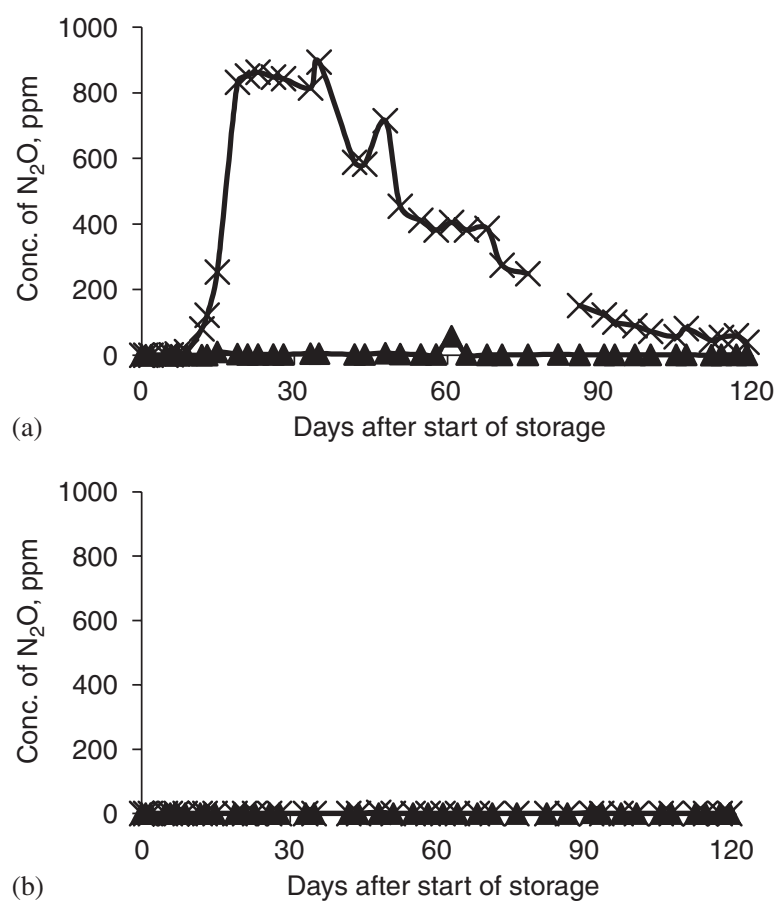

Fig. 3. Concentrations of nitrous oxide $\left(\mathrm{N}_{2} \mathrm{O}\right)$ in solids separated from pig slurry when stored in an uncovered (a) and covered (b) heap. Concentrations were determined $0.1 \mathrm{~m}$ below heap surface $-\times-$, in the centre of heaps $-\mathbf{\Lambda}-$, and in ambient air - .

however a minor increase in $\mathrm{CH}_{4}$ concentration was observed in the centre of the covered heap toward the end of the storage period (Fig. 4b).

\subsection{Storage loss of mass, carbon and nitrogen determined by mass balance}

Uncovered material had a higher mass loss (water and organic matter) than covered material. The average $\mathrm{pH}$ of the material was reduced during storage either with or without covering, but the $\mathrm{pH}$ of the covered material after storage $(\mathrm{pH} \mathrm{8.3)} \mathrm{was}$ significantly higher than that of the uncovered material ( $\mathrm{pH}$ 7.1). (Table 1). Covering reduced storage loss of DM, whereas concentration of DM was unchanged by storage (Table 2). Ammonium $\left(\mathrm{NH}_{4}\right)$ concentration was significantly reduced by storage in an uncovered heap, while it was increased by $20 \%$ in a covered heap (Table 2 ). Approximately $30 \%$ of the initial carbon content was lost from the uncovered heap during storage, while only $7 \%$ of the initial carbon was lost from the covered heap (Table 3). Of the initial total nitrogen content $15 \%$ was lost from the uncovered heap, while only $6 \%$ was lost from the covered heap (Table 3).
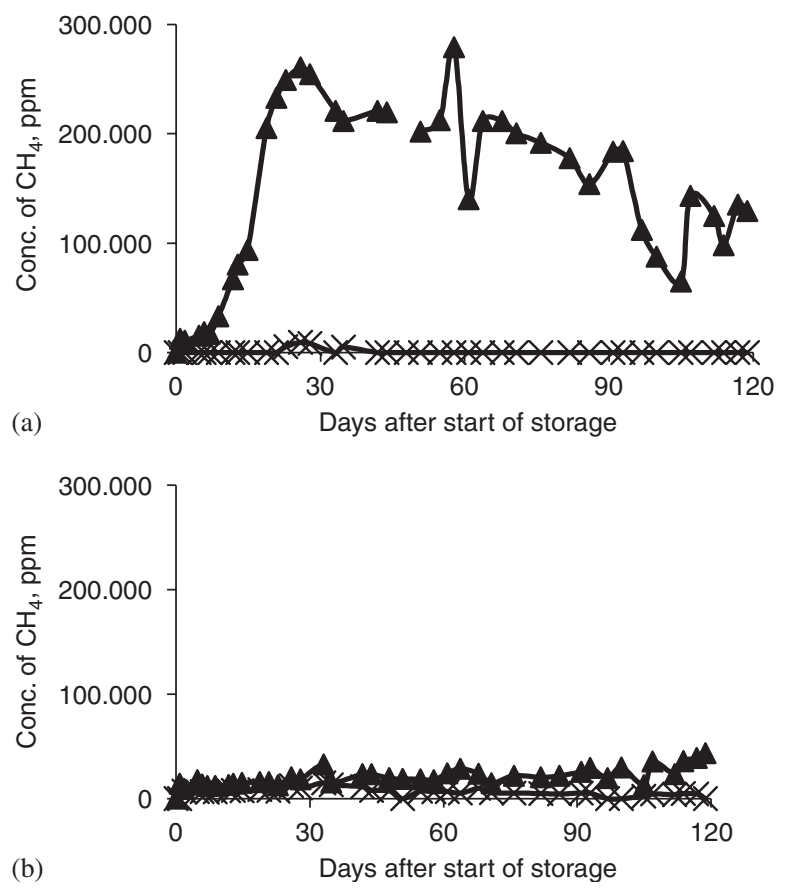

Fig. 4. Concentrations of methane $\left(\mathrm{CH}_{4}\right)$ inside solids separated from pig slurry when stored in an uncovered (a) and covered (b) heap. Concentrations were determined $0.1 \mathrm{~m}$ below heap surface $-\times-$, in the centre of heaps $-\mathbf{\Lambda}-$, and in ambient air - .

Table 1

Weight (ww) and $\mathrm{pH}$ of the covered and the uncovered manure before and after storage

\begin{tabular}{llllll}
\hline \multirow{2}{*}{ Treatment } & \multicolumn{2}{l}{ Weight, $\mathrm{kg}$} & & \multicolumn{2}{l}{$\mathrm{PH}$} \\
\cline { 2 - 3 } \cline { 5 - 6 } & Uncover & Cover & & \multicolumn{2}{l}{ Uncover Cover } \\
\hline Start of storage & 6540 & 6880 & $9.1 \mathrm{a}$ & $9.0 \mathrm{a}$ \\
End of storage & 5860 & 6620 & & $7.1 \mathrm{~b}$ & $8.3 \mathrm{c}$ \\
Loss of initial content & $680(10.4 \%)$ & $260(3.8 \%)$ & & \\
\hline
\end{tabular}

Values in parentheses represent loss in per cent of initial weight. Values followed by same letter are not significantly different $(P<0.05 \%)$.

\subsection{Emission of $\mathrm{N}_{2} \mathrm{O}, \mathrm{CH}_{4}$ and $\mathrm{NH}_{3}$}

The emission rate of $\mathrm{N}_{2} \mathrm{O}$ from the uncovered heap peaked after $14 \mathrm{~d}$ of storage; thereafter the emission rate gradually decreased to $2 \mathrm{~g}$ $\mathrm{N}_{2} \mathrm{O}-\mathrm{N} \mathrm{d}^{-1} \mathrm{t}^{-1}$ after $120 \mathrm{~d}$ of storage. An increase in $\mathrm{N}_{2} \mathrm{O}$ emission was observed following irrigation during the first $80 \mathrm{~d}$ of storage (Fig. 5a). The emission rate of $\mathrm{CH}_{4}$ from the uncovered heap peaked after $30 \mathrm{~d}$ of storage, whereafter the 
Table 2

Concentration before and after storage, and storage loss of dry matter (DM) and ammonium nitrogen $\left(\mathrm{NH}_{4}-\mathrm{N}\right)$ of the covered and the uncovered manure

\begin{tabular}{|c|c|c|c|c|c|}
\hline & \multirow[t]{2}{*}{ Units } & \multicolumn{2}{|l|}{$\mathrm{DM}$} & \multicolumn{2}{|l|}{$\mathrm{NH}_{4}-\mathrm{N}$} \\
\hline & & Uncover & Cover & Uncover & Cover \\
\hline Start of storage & $\mathrm{kg} \mathrm{t}^{-1}(\mathrm{ww})$ & $380 \mathrm{a}$ & $377 \mathrm{a}$ & $5.3 \mathrm{a}$ & $5.2 \mathrm{a}$ \\
\hline End of storage & $\mathrm{kgt}^{-1}(\mathrm{ww})$ & $373 \mathrm{a}$ & $373 \mathrm{a}$ & $3.2 \mathrm{~b}$ & $7.7 \mathrm{c}$ \\
\hline Loss & $\mathrm{kg} \mathrm{t}^{-1}$ (initial ww) & $45.9(12.1 \%)$ & $18.1(4.8 \%)$ & $2.4(45.9 \%)$ & $-1.1(-20.4 \%)$ \\
\hline
\end{tabular}

Values in parentheses represent loss in per cent of initial content. Values followed by same letter are not significantly different $(P<0.05 \%)$.

Table 3

Concentration before and after storage, and storage loss of nitrogen $(\mathrm{N})$ and carbon $(\mathrm{C})$ of the covered and the uncovered manure

\begin{tabular}{|c|c|c|c|c|c|}
\hline & \multirow[t]{2}{*}{ Units } & \multicolumn{2}{|l|}{ Total N } & \multicolumn{2}{|l|}{ Total C } \\
\hline & & Uncover & Cover & Uncover & Cover \\
\hline Start of storage & $\mathrm{kg} \mathrm{t}^{-1}(\mathrm{ww})$ & $13.6 \mathrm{a}$ & $13.6 \mathrm{a}$ & $119.6 \mathrm{a}$ & $117.9 \mathrm{a}$ \\
\hline End of storage & $\mathrm{kgt}^{-1}(\mathrm{ww})$ & $13.0 \mathrm{a}$ & $13.4 \mathrm{a}$ & $96.2 \mathrm{~b}$ & $113.9 \mathrm{a}$ \\
\hline Loss of initial content & $\mathrm{kg} \mathrm{t}^{-1}$ (initial ww) & $2.0(14.7 \%)$ & $0.80(5.6 \%)$ & $33.4(27.9 \%)$ & $8.3(7.0 \%)$ \\
\hline $\mathrm{NH}_{3}-\mathrm{N}$ or $\mathrm{CH}_{4}-\mathrm{C}$ emission & $\mathrm{kg} \mathrm{t}^{-1}$ (initial ww) & $0.042(0.3 \%)$ & $0.037(0.3 \%)$ & $1.6(1.3 \%)$ & $0.2(0.17 \%)$ \\
\hline $\mathrm{N}_{2} \mathrm{O}-\mathrm{N}$ or $\mathrm{CO}_{2}-\mathrm{C}$ emission & $\mathrm{kg} \mathrm{t}^{-1}$ (initial ww) & $0.65(4.8 \%)$ & $0.005(0.04 \%)$ & $30.0(25.1 \%)$ & $2.2(1.9 \%)$ \\
\hline Not accounted for & $\mathrm{kg} \mathrm{t}^{-1}$ (initial ww) & $1.3(9.6 \%)$ & $0.76(5.3 \%)$ & $1.8(1.5 \%)$ & $5.9(4.9 \%)$ \\
\hline
\end{tabular}

Values in parentheses represent loss in per cent of initial content. Values followed by same letter are not significantly different $(P<0.05 \%)$.

emission rate dropped to low levels after $40 \mathrm{~d}$ of storage (Fig. 5b). Ammonia emission from the uncovered heap was high for the first $20 \mathrm{~d}$ of storage. Covering the heap reduced the initial emission of $\mathrm{NH}_{3}$; however, $\mathrm{NH}_{3}$ was emitted at a low rate until $40 \mathrm{~d}$ after start of storage (Fig. 5c).

Emission rates of $\mathrm{N}_{2} \mathrm{O}$ and $\mathrm{CH}_{4}$ during storage of the separated manure solids were considerably reduced by covering the heap (Fig. 5).

The cumulated emissions of $\mathrm{CH}_{4}$ and $\mathrm{CO}_{2}$ were reduced by $88 \%$ and $93 \%$, respectively, by covering the heap (Table 3). For the uncovered heap, the carbon emission loss was almost equal to the carbon loss measured by mass balance, whereas it accounted for less than $30 \%$ in the covered heap. Ammonia emission was reduced by $12 \%$ by covering, while nitrogen loss via the $\mathrm{N}_{2} \mathrm{O}$ pathway was reduced by $99 \%$. Ammonia and $\mathrm{N}_{2} \mathrm{O}$ emissions comprised approximately one-third of the total $\mathrm{N}$ loss from the uncovered heap (determined by mass balance analysis), but only $6 \%$ of the measured total nitrogen loss from the covered heap.

\section{Discussion}

\subsection{Aeration of heaps}

Covering was found to have a major impact on composting activity and on the production and emission of greenhouse gases and ammonia. Similar effects of the combined compaction and covering of cattle manure heaps have been reported by Sommer (2001) and Chadwick (2005). The solid fraction produced by slurry separation is a fibrous product, which allows air to flow into the heap (Miller et al., 1989). Air inflow, and thereby oxygenation, may be further increased by the upward air flow generated by the heat produced by the composting process (Oenema et al., 2001). During passage through the material in the heap, the $\mathrm{O}_{2}$ concentration of inflowing air is depleted by the microbial organisms degrading the readily digestible components of the manure (Miller et al., 1989). With depletion of the readily available digestible components, the aerobic zone moves deeper and deeper inside the heap over the course of the storage period, as illustrated in Fig. 1. For the first two months of storage, the 

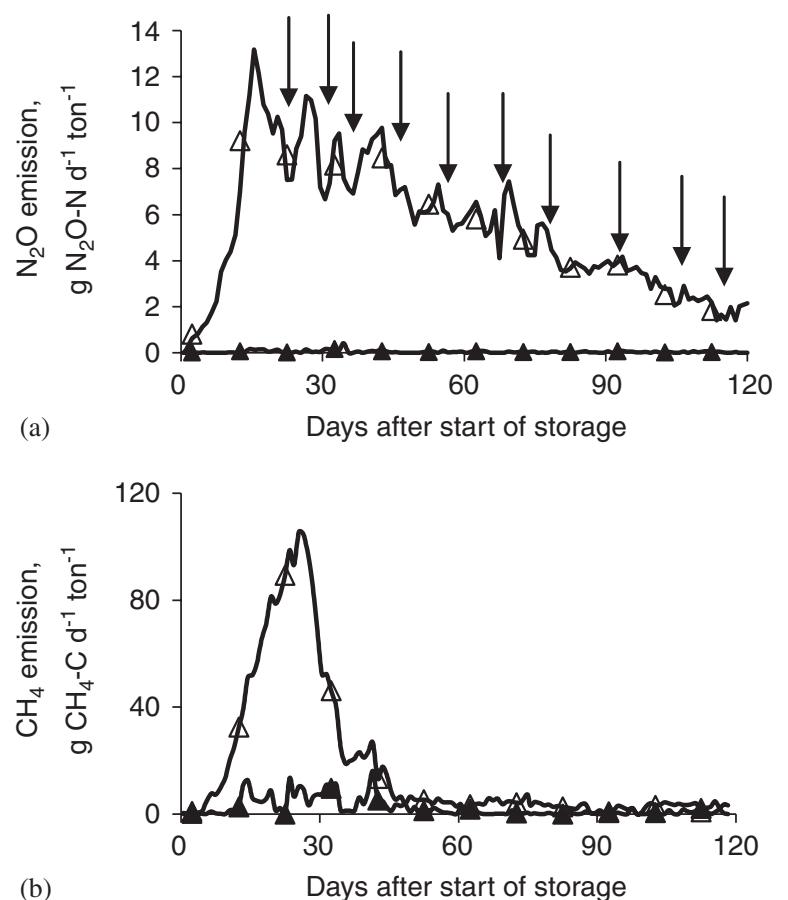

(b)

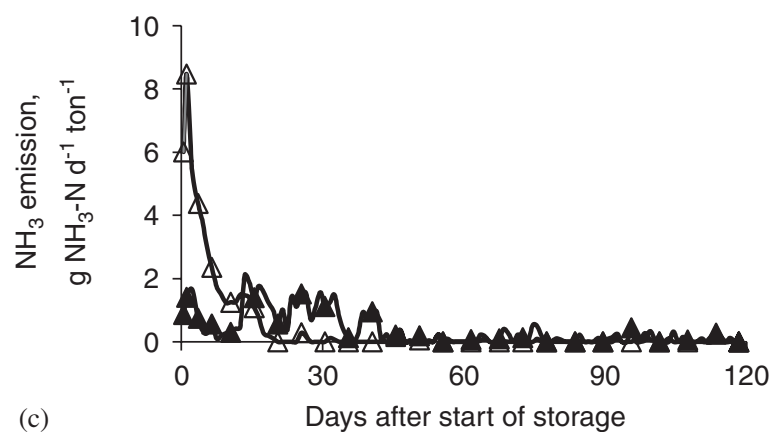

Fig. 5. Emission rate of nitrous oxide $\left(\mathrm{N}_{2} \mathrm{O}\right)(\mathrm{a})$, methane $\left(\mathrm{CH}_{4}\right)$ (b), and ammonia $\left(\mathrm{NH}_{3}\right)$ (c) during storage of solids separated from pig slurry stored uncovered $-\triangle-$ and covered $-\boldsymbol{\Delta}-$. Irrigation of the uncovered heap is shown by arrows.

centre of the uncovered heap was thus found to be partly anaerobic, while anaerobic conditions were only observed in the first week $0.1 \mathrm{~m}$ below the surface. Anaerobic conditions remained for a much longer period inside the bulk of the covered manure, as covering restricts inflow of air into manure heaps (Sommer, 2001).

\subsection{Temperature}

Composting has been defined as the degradation of organic matter performed by aerobic microorganism when oxygen is available (Gray et al., 1971). This catabolic process produces energy that increases the temperature of the organic material, which in turn increases the microbial activity and thus the further degradation of the material. When the inflow of oxygen into the heap is reduced by covering, anaerobic degradation of organic matter takes place (Brock and Madigan, 1988). However, as the energy released by anaerobic degradation is less than that released by aerobic degradation, anaerobic degradation of solid manure does not increase heap temperature, which restricts microbial activity and thus the degradation of organic matter. Loss of total carbon during storage is therefore reduced by covering heaps of organic material.

\subsection{Production and emission of methane}

While $\mathrm{CO}_{2}$ is the main end product of the aerobic degradation of organic carbon, the greenhouse gases $\mathrm{CH}_{4}$ and $\mathrm{CO}_{2}$ are the main end products of anaerobic carbon degradation (Brock and Madigan, 1988). The production rate of $\mathrm{CH}_{4}$ is highly dependent on the temperature range (Husted, 1994; Khan et al., 1997). Due to the combination of anaerobic conditions and increasing temperature, concentration of $\mathrm{CH}_{4}$ in the gas phase in the centre of the uncovered heap increased over the first $30 \mathrm{~d}$ of storage. The subsequent decline in $\mathrm{CH}_{4}$ concentration, after one month of storage, indicates that aerobic conditions had moved toward the centre of the heap. The pattern of aeration and $\mathrm{CH}_{4}$ production caused the emission of $\mathrm{CH}_{4}$ to peak $30 \mathrm{~d}$ after establishment of the heap. The total emission of $\mathrm{CH}_{4}$ from the uncovered heap accounted for $1.3 \%$ of the initial carbon content. Lower $\mathrm{CH}_{4}$ emission has been reported by Osada et al. (2001), who found that $\mathrm{CH}_{4}$ emission during storage of cattle deep litter represented $0.01 \%$ of total $\mathrm{C}$; however, this low carbon loss via the $\mathrm{CH}_{4}$ pathway might partly be explained by the shorter storage period (less than two months) and smaller heap size used, both of which reduced the size of the anaerobic zone inside the heap. Concentration of $\mathrm{CH}_{4}$ in the bulk of the manure was reduced considerably by covering the heap, despite the fact that anaerobic conditions were observed inside the covered heap for most of the storage period. This indicates that $\mathrm{CH}_{4}$ production inside the bulk of the covered manure was restricted by the lower temperature observed in covered material. Similar results have been observed by Husted (1994), who found that emission of $\mathrm{CH}_{4}$ from dung heaps was reduced by between 2.7 and 10.3 times when heap 
temperatures were decreased by $10^{\circ} \mathrm{C}$. The emission of $\mathrm{CH}_{4}$ from the covered, cooler heap was therefore reduced to $0.2 \%$ of the initial carbon content, which equals only $13 \%$ of the $\mathrm{CH}_{4}$ emitted from the uncovered heap. The imbalance between mass of carbon emitted and the carbon loss determined by the mass balance method is expected to be caused by the inaccuracy of the mass balance method and by emission of carbon monoxide (CO) (Hellebrand and Kalk, 2001b).

\subsection{Production and emission of nitrous oxide}

In the uncovered heap, $\mathrm{N}_{2} \mathrm{O}$ concentrations in the gas phase increased after $30 \mathrm{~d}$ of storage in the outer layers and after $60 \mathrm{~d}$ of storage at the centre of the heap. This indicates that the $\mathrm{N}_{2} \mathrm{O}$ production zone moved toward the centre of the heap, together with the aerobic zone. $\mathrm{N}_{2} \mathrm{O}$ production was negligible when air inflow was restricted by covering, which indicates that aeration of the covered material was too low to allow nitrification. Emission loss of $\mathrm{N}_{2} \mathrm{O}$ from the uncovered heap peaked after $60 \mathrm{~d}$ of storage, declining gradually to low values after $120 \mathrm{~d}$ of storage. A similar pattern of $\mathrm{N}_{2} \mathrm{O}$ emission has been observed by Hellebrand and Kalk (2001a) and by Sommer and Møller (2000). According to Hellmann et al. (1997), the delay in $\mathrm{N}_{2} \mathrm{O}$ emission is caused by the fact that most nitrifying and denitrifying microorganisms are not thermophilic. Production of $\mathrm{N}_{2} \mathrm{O}$ by nitrifying and denitrifying processes thus only takes place after heat production has diminished. The total nitrogen loss via the $\mathrm{N}_{2} \mathrm{O}$ pathway accounted for almost $5 \%$ of the initial nitrogen content of the uncovered heap. Lower relative levels of $\mathrm{N}_{2} \mathrm{O}$ loss have been observed by Sommer and Møller (2000) and Osada et al. (2001), who found that nitrogen loss from small heaps of dairy deep litter by the $\mathrm{N}_{2} \mathrm{O}$ pathway amounted to $0.2 \%$ and $0.8 \%$, respectively, of the initial total $\mathrm{N}$ content. Hellebrand (1998) modelled $\mathrm{N}_{2} \mathrm{O}$ emission during the composting of green waste, and found that it accounted for approximately $0.5 \%$ of the initial total $\mathrm{N}$ content. The higher $\mathrm{N}_{2} \mathrm{O}$ emission found in the present study may be explained by the higher density of the solids separated from slurry, relative to that of deep litter from dairy cattle production or of green manure. Higher density of solid manure reduces ammonia emission (Sommer, 2001), which increases the amount of ammonium available for nitrification. Thus, $\mathrm{N}_{2} \mathrm{O}$ is emitted at a higher rate from solid manure heaps of higher density (Sommer and Møller, 2000). Covering the manure heap nearly eliminated the emission loss of $\mathrm{N}_{2} \mathrm{O}$ to account only $0.2 \%$ of initial nitrogen content. This indicates that nitrification processes, and thereby denitrification processes, were restricted by low gas-phase oxygen concentrations within the covered material.

\subsection{Ammonia emission}

The emission of $\mathrm{NH}_{3}$ from uncovered material was observed to be high immediately after heap establishment; thereafter, the emission rate gradually declined to nearly zero within a few weeks of storage. A lower initial $\mathrm{NH}_{3}$ emission rate was observed from the covered heap; however, emission continued at a low rate for the first $60 \mathrm{~d}$ of storage. Total emission loss of $\mathrm{NH}_{3}$ was thus only reduced by $12 \%$ by covering the heap. A higher reduction has been observed by Chadwick (2005), who found that a combination of plastic covering and compaction of cattle manure heaps reduced $\mathrm{NH}_{3}$ emission by $90 \%$ in one study period, while insignificant reductions were observed during two other study periods. Covering poultry manure heaps with PVC sheets reduced ammonia emission by $90 \%$ (Sagoo et al., 2005). The storage loss of $\mathrm{NH}_{3}$ from uncovered, separated solid manure was found to be lower than the storage loss of $\mathrm{NH}_{3}$ from other types of solid manure, which, depending on manure type and climatic conditions, has been determined to account for $0.3-34 \%$ of the initial nitrogen content (Petersen et al., 1998; Sommer and Dahl, 1999; Møller et al., 2000b; Misselbrook et al., 2001; Webb et al., 2001; Rogstrand et al., 2005). The low ammonia emission loss found by the present study may be due to the high density of the solids separated from pig slurry (Sommer and Møller, 2000; Sommer, 2001). As well, the lower ammonia emission might partly stem from a more readily available carbon source in the solid manure produced by separation; the high straw content of cattle and pig solid manure results in a high content of less-degradable carbon sources, such as lignin and hemicelluloses. A high content of readily available carbon in the separated solid manure triggers high microbial activity and thus the immobilisation of ammonium in the microbial biomass, which restricts $\mathrm{NH}_{3}$ emission (Fassen and Diek, 1979; Kirchmann, 1985).

\subsection{Nutrient value}

Covering reduced the total $\mathrm{N}$ loss from $15 \%$ to $6 \%$ of the initial nitrogen content, but the total $\mathrm{N}$ 
concentration of the manure following storage ( $\mathrm{kg} \mathrm{N} \mathrm{t}^{-1} \mathrm{ww}$ ) was not influenced by covering. This was due to the higher loss of water and dry matter during uncovered storage. Concentration of $\mathrm{NH}_{4}$ in uncovered manure was significantly reduced during storage by a combination of $\mathrm{NH}_{3}$ emission and denitrification processes, which together reduced the $\mathrm{NH}_{4}$ content by $46 \%$. In contrast, the content of $\mathrm{NH}_{4}-\mathrm{N}$ in the covered manure increased by $20 \%$, indicating that net mineralisation of organically bound nitrogen took place in the covered heap during storage. $\mathrm{NH}_{4}$ is a readily available plant nutrient, so covering thus increases the nutrient value of separated solids. However, due to the higher $\mathrm{pH}$ and $\mathrm{NH}_{4}$ content of covered material, the benefits of covering may only be realized if the manure is rapidly incorporated following land spreading. Otherwise the ammonium conserved during storage may subsequently be lost as ammonia during land spreading (Hansen, 2004; Sagoo et al., 2005).

\section{Summary}

The oxygenation level inside heaps of solids separated from pig slurry was found to influence the production and emission of greenhouse gases during the storage period. Covering delayed aeration of the stored manure; this reduced internal heat production, degradation of organic matter, and emission of greenhouse gases and ammonia. Approximately $15 \%$ of the initial nitrogen content of the solids separated from pig slurry was found to be lost when the separated solids were stored uncovered. Almost $5 \%$ of the initial nitrogen content was found to be lost as $\mathrm{N}_{2} \mathrm{O}$, while only $0.3 \%$ was lost as $\mathrm{NH}_{3}$. Covering reduced the emission of $\mathrm{N}_{2} \mathrm{O}$ by $99 \%$, and the emission of $\mathrm{NH}_{3}$ by $12 \%$. Of the initial carbon content, $28 \%$ was lost during uncovered storage; the majority of this loss was emitted as carbon dioxide $(25 \%)$, while $1.3 \%$ was emitted as $\mathrm{CH}_{4}$. Covering was found to reduce $\mathrm{CH}_{4}$ emission by $88 \%$. As the study was not replicated, no statistical significance can be placed on the quoted reductions in gaseous emissions.

\section{Acknowledgements}

This project was financially supported by the Danish Research Centre for Organic Farming and the Greenhouse Gas Emission Foundation. The authors thank Inge Marie Gregersen and Karsten Sørensen for their valuable technical assistance.

\section{References}

Amon, B., Amon, T.H., Boxberger, J., Alt, C.H., 2001. Emissions of $\mathrm{NH}_{3}, \mathrm{CH}_{4}$ from dairy cows housed in a farmyard manure tying stall (housing, manure storage, manure spreading). Nutrient Cycling in Agroecosystems 60, 103-113.

Beck-Friis, B.G., 2001. Emissions of ammonia, nitrous oxide and methane during composting of organic household waste. Ph.D. Dissertation, Acta Universitatis Agriculturae Sueciae. Agraria, 266. Swedish University of Agricultural Sciences, Sweden. pp. 0-24.

Bremner, J.M., Blackmer, S.M., 1989. Nitrous oxide emissions from soils during nitrification of fertilizer nitrogen. Science 199, 295-296.

Brock, T.D., Madigan, M.T., 1988. Methane producing bacteria: methanogensis. In: Brock, T.D., Madigan, M.T. (Eds.), Biology of Microorganisms. Prentice-Hall, International (UK), London, pp. 773-788.

Chadwick, D.R., 2005. Emissions of ammonia, nitrous oxide and methane from cattle manure heaps: effect of compaction and covering. Atmospheric Environment 39, 787-799.

Dewes, T., 1996. Effect of $\mathrm{pH}$, temperature, amount of litter and storage density on ammonia emissions from stable manure. Journal of Agricultural Science 127, 501-509.

Eghball, B., Power, J.F., Gilley, J.E., Doran, J.W., 1997. Nutrient, carbon, and mass loss during composting of beef cattle feedlot manure. Journal of Environmental Quality 26, 189-193.

Fassen van, H.G., Diek van, H., 1979. Nitrogen conversions during the composting of manure straw mixtures. In: Grosbard, E. (Ed.), Straw Decay and its Effect on Disposal and Utilization. J Wiley, New York, pp. 113-120.

Gray, K.R., Sherman, K., Biddlestone, A.J., 1971. A review of composting, Part 1. Process Biochemistry 6, 32-36.

Hansen, M.N., 2004. Influence of storage of deep litter manure on ammonia loss and uniformity of mass and nutrient distribution following land spreading. Biosystems Engineering 87, 99-107.

Hao, X., Chang, C., 2001. Gaseous $\mathrm{NO}, \mathrm{N}_{2} \mathrm{O}$, and $\mathrm{NH}_{3}$ loss during cattle feedlot manure composting. Phyton - Annales Rei Botanicae 41, 81-93.

Hellebrand, H.J., 1998. Emission of nitrous oxide and other trace gases during composting of grass and green waste. Journal of Agricultural Engineering Research 69, 365-375.

Hellebrand, H.J., Kalk, W.D., 2001a. Emission of methane, nitrous oxide, and ammonia from dung windrows. Nutrient Cycling in Agroecosystems 60, 83-87.

Hellebrand, H.J., Kalk, W.D., 2001b. Emission of carbon monoxide during composting of dung and green waste. Nutrient Cycling in Agroecosystems 60, 79-82.

Hellmann, B., Zelles, L., Palojärvi, A., Bay, Q., 1997. Emission of climate-relevant trace gases and succession of microbial communities during open-windrow composting. Applied Environmental Microbiology 63, 1011-1018.

Houghton, J.T., Meira Filho, L.G., Callander, B.A., Harris, N., Kattenberg, A., Marskell, K. (Eds.), 1996. Climate change 1995: The Science of Climate Change. Intergovernmental 
Panel on Climate Change. Cambridge University Press, Cambridge, UK.

Hüther, L., Schuchardt, F., Wilke, T., 1997. Emissions of ammonia and greenhouse gases during storage and composting of animal manures. In: Voermans, J.A.M., Monteney, G.J. (Eds.), Ammonia and Odour Control from Animal Production Facilities. Elsevier, Amsterdam, pp. 324-327.

Husted, S., 1994. Seasonal variation in methane emission from stored slurry and solid manures. Journal of Environmental Quality 23, 585-592.

Kirchmann, H., 1985. Losses, plant uptake and utilization of manure nitrogen during a production cycle. Acta Agriculturae Scandivavica (Supplementum 24), 28-40.

Khan, R.Z., Müller, C., Sommer, S.G., 1997. Micrometeorological mass balance technique for measuring $\mathrm{CH}_{4}$ emission from stored cattle slurry. Biology and fertility of soils 24 (4), 442- 444.

Miller, F.C., Harper, E.R., Macaluley, B.J., 1989. Field examination of temperature and oxygen relationships in mushroom composting stacks - consideration of stack oxygenation based on utilization and supply. Austrian Journal of Experiments, Agriculture 29, 741-750.

Misselbrook, T.H., Balsdon, S., Pain, B.F., Gibbs, P.A., Parkinson, R.J., 2001. Gaseous emissions from on-farm composting of cattle farm yard manure. In: Sangiorgi, F. (Ed.), Technology Transfer: Proceedings of the Ninth International RAMIRAN 2000 Workshop, Gargnano, Italy, 6-9 September 2000, Cemagref, France, pp. 373-375.

Møller, H.B., Lund, I., Sommer, S.G., 2000a. Solid-liquid separation of livestock slurry: efficiency and cost. Bioresource Technology 74, 223-229.

Møller, H.B., Sommer, S.G., Andersen, B.H., 2000b. Nitrogen mass balance in deep litter during the pig fattening cycle and during composting. Journal of Agricultural Science 135, 287-296.

Møller, H.B., Sommer, S.G., Ahring, B.K., 2002. Separation efficiency and particle size distribution in relation to manure type and storage conditions. Bioresource Technology 85, 189-196.

Oenema, O., Bannink, A., Sommer, S.G., Velhof, G.L., 2001. Gaseous nitrogen emissions from livestock farming systems. In: Follett, R.F., Hartfield, J.L. (Eds.), Nitrogen in the Environment: Sources, Problems, and Management. Elsevier, Amsterdam, pp. 255-290.

Osada, T., Sommer, S.G., Dahl, P., Rom, H.B., 2001. Gaseous emission and changes in nutrient composition during deep litter composting. Acta Agriculturae Scandinavica Section B-Soil and Plant Science 51, 137-142.
Petersen, S.O., Lind, A.M., Sommer, S.G., 1998. Nitrogen and organic matter losses during storage of cattle and pig manure. Journal of Agricultural Science 130, 69-79.

Rogstrand, G., Rodhe, L., Tersmeden, M., Bergström, J., 2005. Evaluation of three approaches to decrease ammonia emission from solid manure facilities. In: Pilar, M., et al. (Eds.), Sustainable Organic Waste Management for Environmental Protection and Food Safety. FAO and CSIS 2005, Murcia, Spain. Proceedings of the 11 th International RAMIRAN Conference 2004, Murcia, Spain, 6-9 October 2004, vol. 1, pp. $257-260$

Rypdal, K., 2002. General guidance and procedures for estimating and reporting national GHG emission for agriculture. DIAS report, Plant production No. 81. Ministry of Food, Agriculture and Fisheries, Danish Institute of Agricultural Sciences. pp. 16-36.

SAS Institute, 1988. SAS/STAT: User's Guide, release 6.03 edition. SAS Institute, Cary, NC.

Safely, L.M., Cassada, M.E., Woodbury, J.W., Roos, K.F., 1992. Global methane emissions from livestock and poultry manure. USEPA Rep. 400/1-91/048. USEPA, Washington, DC.

Sagoo, E., Williams, J.R., Chambers, B.J., Boyles, R., Matthews, R., Chadwick, D.R., 2005. Integrated management practices to minimize losses and maximise crop nitrogen value of broiler litter. In: Pilar, M., et al. (Eds.), Sustainable Organic Waste Management for Environmental Protection and Food Safety FAO and CSIS 2005, Murcia, Spain. Proceedings of the 11th International RAMIRAN Conference 2004, Murcia, Spain, 6-9 October 2004, vol. 1, pp. 249-252.

Sommer, S.G., 2001. Effect of composting on nutrient loss and nitrogen availability of cattle deep litter. European Journal of Agronomy 14, 123-133.

Sommer, S.G., Dahl, P., 1999. Nutrient and carbon balance during the composting of deep litter. Journal of Agricultural Science 74, 145-153.

Sommer, S.G., Møller, H.B., 2000. Emission of greenhouse gases during composting of deep litter from pig production - effect of straw content. Journal of Agricultural Sciences (Cambridge) $134,327-335$.

UNFCCC, 1999. The Kyoto Protocol to the United Nations Framework Convention on Climate Change. http://unfccc.int/essential_background/convention/items/2627.php.

Webb, J., Chadwick, D., Ellis, S., 2001. Will storing farmyard manure in compact anaerobic heaps be a simple and effective means of reducing ammonia emissions? In: Sangiorgi, F. (Ed.), Technology Transfer: Proceedings of the 9th International RAMIRAN 2000 Workshop, Gargnano, Italy, 6-9 September 2000, Cemagref, France, pp. 161-166. 